\title{
Room for manoeuvre in time of the workforce in dairy production systems ${ }^{1}$
}

\author{
Joel Carneiro dos Santos Filho², Nathalie Hostiou ${ }^{3}$, Julio César Damasceno ${ }^{4}$, Benoît Dedieu ${ }^{3}$ \\ 1 Project financed by CAPES. \\ ${ }^{2}$ Doctoral student of Animal Production by Universidade Estadual de Maringá (UEM). CAPES fellow. \\ ${ }^{3}$ Institut National de la Recherche Agronomique, UMR 1273 Métafort, Theix - 63122 Saint-Genès - Champanelle, France. \\ ${ }^{4}$ Universidade Estadual de Maringá - PR, Av. Colombo, 5790, CEP 87020-900. CNPq fellow.
}

\begin{abstract}
The objective of this study was to characterize and to analyze the room for manoeuvre in time in dairy production systems (DPS). Two interviews were conducted in twenty DPS in the Northern region of Paraná, Brazil, with the following objectives: to know the management and practices involving the herd, the land area and the commercialization; and to qualify and evaluate the work organization. In order to build the variables, the repertory grid method was used, and for the typology, the graphic methodology of Bertin adapted to small samples was used. The results showed that the room for manoeuvre in time of the DPS, quantified in hours available per year, varied between the farmers and was related to routine work and seasonal work durations, as well as the autonomy of farmers to perform both works. The routine work was related to the number of cows, but was also explained by the herd management, by the transport equipment for the feed and by the workforce composition. Four types of work organization were identified between sampled DPS, based on room for manoeuvre in time and how they were built. Knowing the room for manoeuvre time and its variables, it is possible to guide the farmers to adjust their dairy production system in order to have more time available for other activities or to develop the dairy production system.
\end{abstract}

Key Words: agriculture work, dairy activity, herd management, labor, production system, work organization

\section{Introduction}

In the last decades, many changes have occurred in rural areas, and one of them concerns to work organization. The volume of work has increased and the number of workers has decreased in the agricultural production systems, especially in familiar agriculture (Ferris et al., 2006; Madelrieux \& Dedieu, 2008; Hostiou \& Dedieu, 2009). These changes were not different in dairy production. This activity is extremely demanding in work and many farmers claim not to have enough time available to spend more on family or off-farm activities. In this sense, according to Ulbricht (2007), workers from dairy production systems (DPS) of the Parana State, Brazil, present a high-level workload (average of 65 hours per week). The work is done everyday including weekends and holidays (Ulbricht, 2007), since there are tasks to be performed daily. The milking and feeding tasks are those which demand more time in the daily routine of these dairy production systems (DPS) (Guillaumin et al., 2004; Chauvat et al, 2003; Ulbricht, 2007).

The knowledge of time available to farmers will be studied through the criterion of room for manoeuvre that allows approaching the pressure exerted on farmers in order for their DPS to be competitive and productive at the same time (Hostiou \& Dedieu, 2012). In the South of Brazil, there is a lack of knowledge about work durations, workloads and time available for farmers in DPS.

The room for manoeuvre is an indicator of the flexibility of work organization (Dedieu et al., 2008; Hostiou \& Dedieu, 2012). Flexibility is the capacity of a system to adapt to continuous environmental disturbances (Nozières et al., 2011).

Work durations influence the room for manoeuvre of farmers but other factors as well. Studies have shown that the room for manoeuvre of farmers is dependent on the DPS size in number of hectares of useful agricultural area and the number of cows (Cournut \& Chauvat, 2010). However, the size of DPS is certainly not the only factor that explains the room for manoeuvre of farmers (Dedieu \& Servière, 2010). The hypothesis of this study is that the room for manoeuvre depends on the size of DPS and the herd management, equipments and cow productivity and also on the workforce composition.

The objective of this study was to characterize and analyze the room for manoeuvre in time in DPS of the North Region of Parana state, Brazil, and to identify the factors explaining the differences observed. 


\section{Material and Methods}

This study was conducted in five municipal districts of the Northern region of Paraná state, Brazil (Colorado, Itaguagé, Nossa Senhora das Graças, Mandaguaçu and Presidente Castelo Branco). In order to proceed to the analysis of the rooms for manoeuvre in time of DPS, 20 DPS were sampled, supported by agricultural extension worker from Instituto Paranaense de Assistência Técnica e Extensão Rural (Instituto EMATER).

The DPS were sampled to characterize a diversity of production structure (herd size, land area), herd feeding, presence of other agricultural and non-agricultural activities and workforce composition (only one worker, two or more workers; familiar workforce and/or other forms) (Table 1). Eight DPS had other agricultural activities than dairy (coffee, vegetable crops, etc.) and six DPS had nonagricultural activities (processing, commercialization).

The data were obtained from two semi-structured interviews conducted with the 20 dairy farmers from June to September of 2010. Each interview had an average duration of an hour and a half. The first interview was done to know the management of DPS and the practices of farmers related to the herd, area, feeding, reform and renovation of the herd and the commercialization of products (Landais, 1992). The second interview was conducted to know the work organization using the QuaeWork method (Qualification and Evaluation of Work in livestock farms) (Hostiou \& Dedieu, 2012).

The QuaeWork method allows to quantify the duration and to qualify forms of work organization on an annual scale related to the process of production, taking into accont the management of the herd and areas, the workforce, the equipments and buildings available, and the combination of activities (agricultural or not) developed by the farmers.

A period defines a time interval - from several weeks to months - that marks certain stability as regards workers available, herd work (the content of the routine work) and the presence or absence of other activities. It also allows considering the adaptation of this organization, according

Table 1 - General characteristics of dairy production systems sampled in the North of Parana state, Brazil

\begin{tabular}{llcc}
\hline Characteristics & Average & Minimum & Maximum \\
\hline Useful agricultural area (ha) & 22.7 & 4.1 & 59.0 \\
Total forage area (ha) & 21.2 & 3.4 & 59.0 \\
Total effective (Animal unit) & 40.5 & 12.3 & 125.8 \\
Effective of cows (heads) & 27 & 9 & 76 \\
Production (thousand liters & 75.17 & 10.95 & 273.75 \\
of milk/year) & & & \\
\hline
\end{tabular}

to the evolution of the technical calendar (plantation, harvesting, etc.), the availability of the workforce (presence and absence of workers) and the interactions between agricultural and non-agricultural activities described by the set-days.

A set-day is characterized by the duration of routine work and the workforce carried out, and its relationships with seasonal work. To address work content ("what"), two types of tasks were defined according to their rhythm and ability of being postponed. The routine work is done almost daily. It usually covers daily animal care (milking, feeding, treatments, etc.) and is quantified in hours per day. Seasonal work includes tasks that are more easily deferrable and (or) concentrable over a given period with the herd, the land area and non-agricultural work (transformation, commercialization, diversification or services). It is quantified in days per year.

The labor component ("who") was handled by differentiating two categories of farm labor. The basic group comprised the workers for whom the agricultural work was their main activity in terms of working time and income, and who organized all the work on the farm (farmer, couple and associates). Labor outside the basic group comprised unpaid help, hired labor, mutual help and agricultural companies.

From the annual calendar, the interviewer describes the work organization, i.e., "who does what" and the duration of work by distinct workers for each period. For example, the farmer "TL" works all over the year, but from May to January, another worker helps him to feed the cows. The farmer also receives help from his family to pack and sell milk from door to door (Table 2).

The room for manoeuvre in time of the farmers is obtained by the calculated available time and corresponds to the time left for the basic group to perform other unrecorded tasks or to have free time for them and their families.

The calculated time available is an indicator of the room for manoeuvre that associates a lower value with the hardness of work and a higher value with the will of the basic group to be free (Dedieu et al., 2000). The formula used to calculate it for the baseline farm unit was:

$$
C T A_{i}=\sum\left(D A_{i} x H A_{i}\right)
$$

Where: CTA - calculated time available; $i$ is a period when routine work has a constant duration; $D A_{i}$ - number of days available during period $i$ (every day except Sunday and days with routine and seasonal work); $H A_{i}$ - hours available [8 hours - (number of hours of routine work performed by the basic group/number of workers of the basic group)]. 
To know the relation between the routine work and the number of cows and also the relation between the seasonal work and the utilized agricultural area (UAA), regression analysis was conducted using software SAS (Statistical Analysis System, version 9.2).

Then, seven variables about the duration of the work, the division of work between worker categories and the room for manoeuvre were defined (Table 3). To build the variables, the repertory grid, a method developed by Girard et al. (2001) was used. This method, used in knowledge engineering, consists of a series of dichotomous attributes built called "variables", defined by the extreme conditions identified in case studies and then, identifying intermediate conditions called "modalities". Three modalities were formalized per variable. Each farm (or DPS) was linked to a modality for each variable (Table 3 ).

In the following step, graphic representations were used to extend the visual cognition as described by Bertin (1977), a method used in animal science (Fiorelli et al., 2007; Hostiou et al., 2010). A cross table with the DPS in rows and the different variables and their modalities in columns were created. The DPS that presented similar visually profiles according to modalities were pooled into groups. Each group was explained using variables of structure, management, equipments and workforce.

Table 2 - Annual calendar of the work organization and management of the dairy production system TL

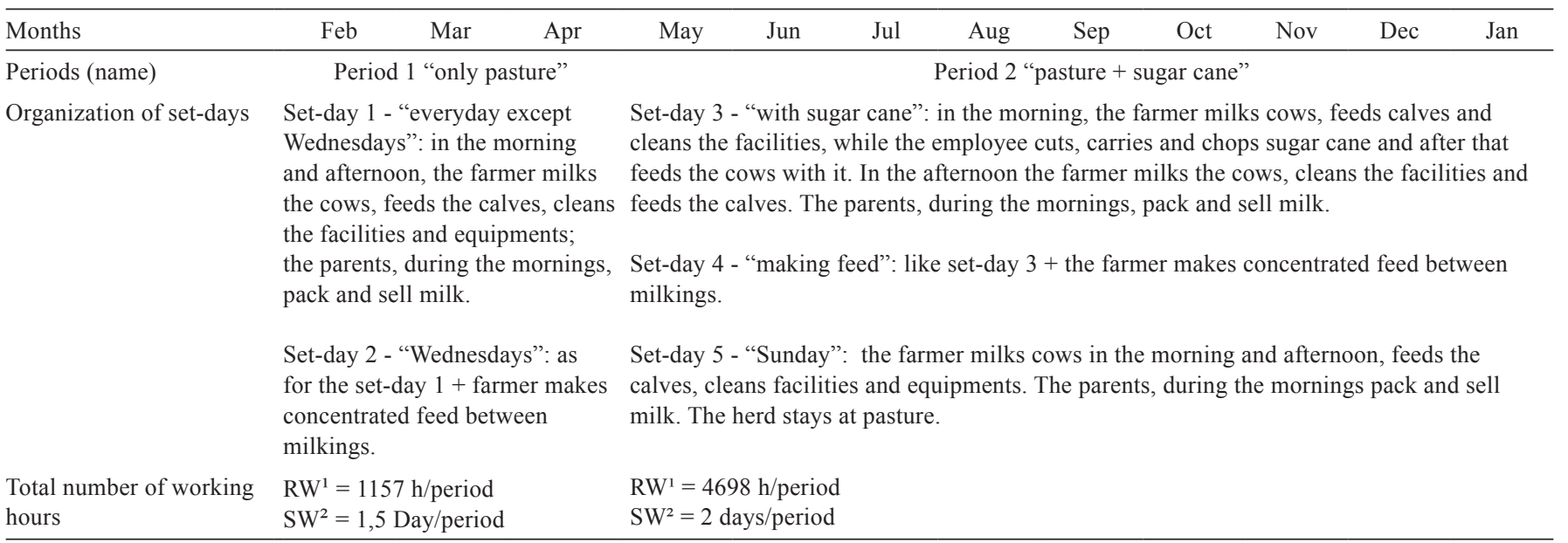

${ }^{1}$ Routine work; ${ }^{2}$ Seasonal work.

Table 3 - Variables of work organization (indicators of room for manoeuvre and the forms of work) with its modalities, used in the repertory grid in graphic representation

\begin{tabular}{|c|c|c|}
\hline Variables & Modalities & Number of dairy production system \\
\hline \multirow[t]{3}{*}{ Calculated time available per worker of the basic group } & 1- low $(<600$ hours/year $)$ & 8 \\
\hline & 2- medium (600 to 1000 hours/year) & 5 \\
\hline & 3- high (>1000 hours/year) & 7 \\
\hline & 2- medium ( 2500 to 5000 hours/year) & 8 \\
\hline & 3- high ( $>5000$ hours/year) & 5 \\
\hline Routine work per worker of the basic group & 1 - low $(<1500$ hours/year $)$ & 8 \\
\hline \multirow[t]{3}{*}{ Autonomy of the basic group for routine works } & 1 - Total $(100 \%)$ & 8 \\
\hline & 2- medium to high $(50$ to $<100 \%)$ & 6 \\
\hline & 3 - low $(<50 \%)$ & 6 \\
\hline \multirow[t]{3}{*}{ Seasonal work (number of days per year) } & 1- low (<20 days/year) & 6 \\
\hline & 2- medium (20 to 40 days/year) & 7 \\
\hline & 3- high ( $>40$ days/year) & 7 \\
\hline & 2- medium ( 35 to $70 \%$ ) & 7 \\
\hline & 3- low $(<35 \%)$ & 5 \\
\hline
\end{tabular}




\section{Results and Discussion}

Among the DPS studied, the margin of room for manoeuvre in time of the basic group, obtained by the calculated time available (Figure 1), presented an average of 960 hours/year and standard deviation of 687 hours/year. On the other hand, the average calculated time available per worker of the basic group was about 732 hours/year, with a standard deviation of 493 hours/year.

These results make it possible to show that the rooms for manoeuvre in time, both the basic group and the worker of the basic group, are very distinct between the DPS sampled.

But how to know if the values of calculated time available found are high or low? Studies conducted in France present an approach of different values of time as references to analyze the calculated time available per worker of the basic group. Cournut \& Chauvat (2010) used as referential a calculated time available of 900 hours/ year/worker of the basic group, and concluded that below this value, the conditions of work at the farm are difficult. Cournut \& Jourdan (2009), showed that "a calculated time available/worker of the basic group below 600 hours/year is considered as to bring stress, and above 1000 hours, the room for manoeuvre in time is enough to generate another activity".

Thus, as there are no scientific studies related to the calculated time available in DPS in the South of Brazil, the parameters of Cournut et al. (2009) were used in this study (Table 3). Given these parameters, it was verified that there are: i) eight DPS presenting average calculated time available of $227 \mathrm{~h} /$ year/worker of the basic group, in which these people have difficulties to perform all work (accounted or not), having to work more than 8 hours per day and/or

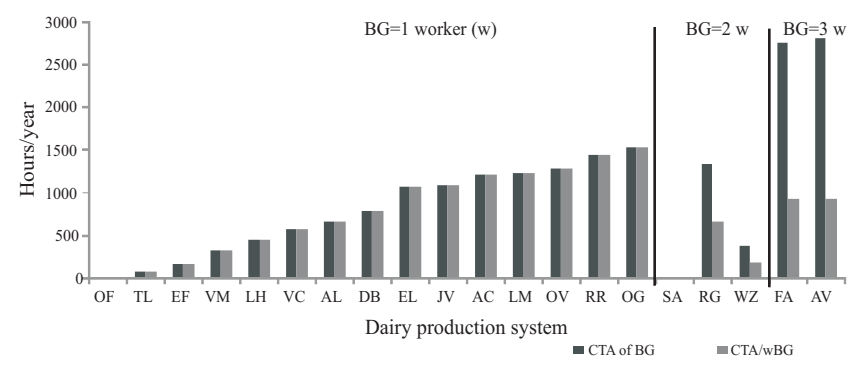

CTA of BG - calculated time available of the basic group; CTA/wBG - calculated time available per worker of the basic group.

Figure 1 - Rooms for manoeuvre in time of the basic group and per worker of basic group of dairy production systems sampled in the Northern region of Parana state, Brazil. failing to perform certain "less important" tasks; ii) five DPS, where each worker of the basic group, presenting an average calculated time, does not have flexible time to perform a new activity; and iii) in seven DPS, each worker of the basic group presents a calculated time available of 1264 hours/year, and has time to do on-farm or off-farm activities.

To better understand the variability of the room of manoeuvre in time found, which is obtained by the calculated time available, it is essential to understand the variability of the routine and seasonal work, which are factors explaining the diversity observed in the DPS studied.

In the sample, routine work with the dairy cattle comprises: milking, feeding, cleaning facilities, cleaning milking equipments and materials and animal displacement. Some of the DPS sampled present routine work linked to agricultural activities (coffee, vegetable crops and small breeding) and non-agricultural activities (transformation and commercialization).

From the regression analysis, the routine work with the herd according to the number of cows, presented linear and significant regression $(\mathrm{P} \leq 0.05)(\mathrm{y}=70.679 \mathrm{x}+1113$, with $\left.\mathrm{R}^{2}=0.5597\right)$. Even so, there is a great variety of routine work (843 to 5190 hours/year) for a fairly reduced interval of cows (20 to 30 cows).

The results show that the routine work with the herd increases according to the number of cows (Figure 2), which was also verified in another study (Hostiou et al., 2010).

However, the routine work does not depend only on the number of cows (Cournut \& Chavaut, 2010). It also depends on the feed supplement adopted in the sample, i.e., the type of the forage provided (sugar cane only or sugar cane plus silage), the period of supply of these forages in the trough, the categories of animals that receive

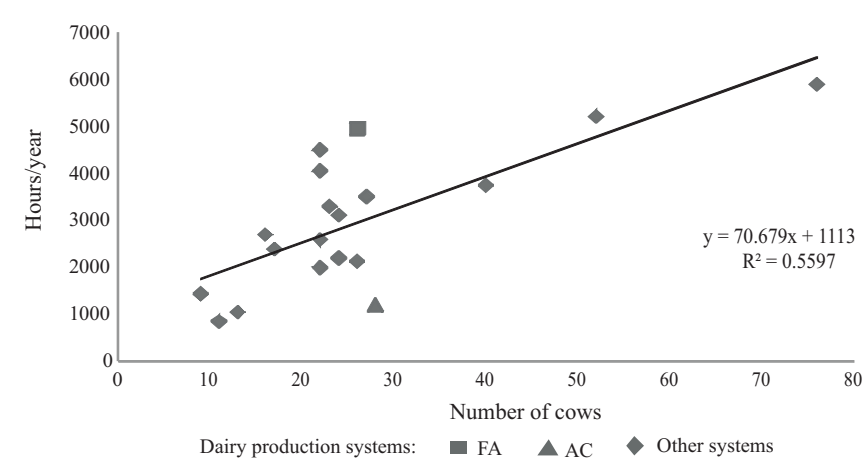

Significant linear regression $(\mathrm{P} \leq 0.05)$.

Figure 2 - Relationship between routine work with the herd (hours/ year) and the number of cows of dairy production systems sampled in the Northern region of Parana state, Brazil. 
these forages in the trough (percentage of herd in animal units), equipments (means of transport of forages) and the productivity of cows.

This result can be illustrated, for example, by two extreme cases (Figure 2, FA and AC) within the range mentioned (20 to 30 cows). The DPS FA, with 4963 hours/ year of routine work is characterized by: highly productive cows, two milking sessions per day, sugar cane as a feed supplement (provided during seven months twice a day and transported by animal cart) and three workers of the basic group to perform the routine work. The DPS AC, with 1200 hours/year of routine work, is characterized by lowproductivity cows, only one milking session daily, use of sugar cane and silage as a feed supplement (obtained during five months, once a day and transported by cart load) and one person of the basic group to perform routine work.

The difference in the routine work between both DPS is explained by the feed management that each one chooses, by the number of daily milking sessions, by the equipments to transport forage and, in the case of the DPS FA, by being more demanding to keep the productivity of the cows. The DPS AC is technically simpler in relation to DPS FA, which leads to a decrease of the routine work over the year (Cournut \& Dedieu, 2005; Dedieu et al., 2006).

In the sample, the routine work can be performed only by the workers of the basic group (total autonomy), with the participation of workers from outside of the basic group (partial autonomy of the basic group). It can be also performed only by workers from outside of the basic group (without autonomy of the basic group). In this study, great variability was identified in the autonomy of the basic group for the routine work. This autonomy ranged from 36 to $100 \%$. On the one hand, in eight DPS, the routine work was performed only by the basic group (total autonomy); on the other hand, in six DPS, the greater part of the routine work was delegated to workers outside the basic group (low autonomy). In an intermediate condition there were six DPS, for which the basic group carried most of the routine work (average and high autonomy). The delegation of a part of the routine work to workers from outside of the basic group contributes to less routine work for the basic group, providing greater room for manoeuvre in time to these people, as observed in other studies in Brazil (Hostiou et al., 2006), France (Cournut \& Chavaut, 2010) and other countries of the Southern Hemisphere (Hostiou, et al., 2010). Also, Errington \& Gasson (1996) observe that the workforce employed (workers outside the basic group) enable the improvement of the flexibility of the system. Therefore, there is a gain in the room for manoeuvre in time to the workers of the basic group when the routine work is shared by workers of outside the basic group. Workers from the basic group have more time to perform unrecorded tasks, more time for family life and/or to develop an activity and/ or start a new activity (agricultural or not).

On the other hand, the seasonal work of the DPS sampled was 34.8 days per year on average and ranged from 3.5 to 214 days per year. The seasonal work per workers from the basic group averaged 15.5 days, varying from 0 to 63 days per year. Different types of seasonal work were identified in the sample: with the herd, forage areas and cultures (coffee, achiote, crop and horticulture). The seasonal work did not present a significant and linear behaviour $(\mathrm{P}=0.7695)$ with the utilized agricultural area, opposing to what was shown in another study (Fagon \& Sabatté, 2011).

The autonomy of the basic group to perform seasonal works ranged from 0 to $100 \%$. There are eight DPS where the basic group did more than $70 \%$ of the seasonal work (high autonomy); however, in five DPS, the basic group performed less than $35 \%$ of the seasonal work (low autonomy) and in seven DPS the autonomy of the basic group to the seasonal work had an intermediate range.

The great variability in the level of autonomy of the basic group to perform the seasonal work in the sample was explained by several factors. When the volume of routine work by worker from the basic group is not high, the farmer has enough time to perform all or most of the seasonal work. The farmer can also share part of the seasonal work according to the availability of workers from outside the basic group. For exemple in the DPS EF, a child, during their school holidays, can aind in the coffee harvesting. Some tasks demand the participation of several individuals from inside and outside the basic group to perform, for example, the preparation of silage in the DPS LM. Thus, many factors can explain the level of autonomy of the basic group for the seasonal work and each production system runs according to its reality. Cournut et al. (2009) also observed great variability of autonomy of the basic group in relation to the seasonal works.

Among the DPS studied, great variability of data was observed, and to better understand it, the DPS were grouped according to the method of Bertin (1977). Four types of DPS were identified according to the variables related to the room for manoeuvre, the routine and seasonal works (Table 4). The type 1 is composed of five DPS in much stressed condition related to work. Each worker from the basic group (1 or 2 workers) practically does not present room for manoeuvre in time (calculated time available of the basic group between 0 and 192 hours/ year). This condition is the result of a high routine work above 3890 hours/year, which is assumed almost totally by 


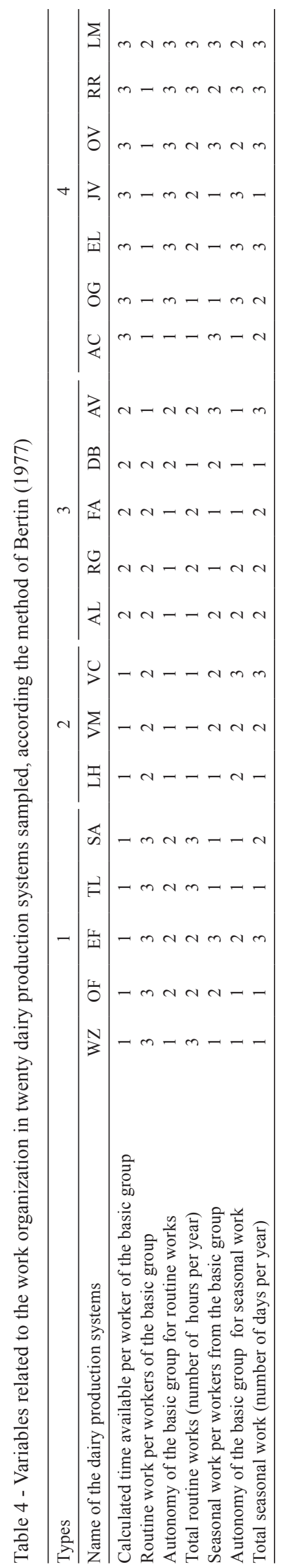

the basic group (above 82\%). Each worker from the basic group assumes more than 2550 hours/year of routine work, which is considered high in the sample. The high routine work may be explained by the use of sugar cane to feed the herd, by sugar cane transport through animal cart (DPS $\mathrm{EF}, \mathrm{OF}, \mathrm{TL}, \mathrm{WZ}$ ) and by the intensification of pasture through manual fertilization (DPS EF, OF, SA, WZ). The long routine work duration can also be explained by the two daily milking sessions (DPS EF, OF, SA, TL) and other agricultural activities such as coffee, crops and fish farming (DPS EF, OF, SA, WZ). There are also other agricultural activities such as commercialization of crops at the farmer market (DPS SA and WZ) and the milk selling in the city (DPS TL). In relation to the seasonal work, the basic group is autonomous (DPS OF, SA, TL, WZ), in other words, they perform every work.

The type 2 is composed of three DPS in a stressed condition related to work, due to a low room for manoeuvre in time (calculated time available ranges from 332 to 584 hours/year). In these DPS, specialized in milk production, the basic group is composed of only one worker. Their low time available is caused mainly because these workers perform all the routine work alone (2041 to 2382 hours/ year). The high routine work duration is due to the two daily milking sessions and the distribution of forages once a day. The DPS VM and VC provide only sugar cane as a supplement and the DPS LH provides sugar cane and corn silage. The DPS LH and VC provide forages to every animal.

The type 3 is composed of five DPS with good flexibility in relation to the work, with a medium room for manoeuvre in time (calculated time available between 664 and 934 hours/year). In this type, the routine work varies from 1942 to 4963 hours/year. The basic group is composed of 1 to 3 workers who perform more than $82 \%$ of the routine work (medium/high and total autonomy). Each worker, after sharing the routine work, performed between 1297 and 1994 hours/year (low and medium routine work per worker from the basic group). The routine work may be explained through the following factors: $65 \%$ to $100 \%$ of the herd receives forage in the cattle trough, using animal cart to transport these forages (DPS RG, FA, DB, AV), which are provided twice a day (DPS AL, RG, FA, AV) and perform milking twice a day (DPS AL, RG, FA, AV).

The type 4 is composed of seven DPS with a high work flexibility, which is confirmed by a high room for manoeuvre in time (calculated time available between 1071 and 1526 hours/year). Only one worker works in the basic group. But the high room for manoeuvre in time may be explained by the high level of delegation of 
both the routine work (more than 50\%), and the seasonal work (more than $58 \%$ ) to workers from outside the basic group (paid workers or unpaid help workers). The routine work duration can also be explained by the simplification of feed management and milk management, as well as by the equipment used to carry more quantity of forage. Simplifying feed management is possible by offering sugar cane and silage in the trough (DPS AC, EL, OV, RR, LM), once a day (DPS AC, OG, EL, OV, RR, LM). The transport of forages is done using tractor cart (DPS AC, JV, LM, RR). And the simplification of milking is by milking only once a day (DPS AC and OG).

The results show that the room for manoeuvre in time did not depend on the size of the herd only, as observed by Cournut \& Chauvat (2010). The DPS farmers have different ways to obtain room for manoeuvre in time as observed in the type 4. One way is based on the simplification of the herd management, as for example, to provide forage once a day instead of two times and one milking session a day. Maseda et al. (2004) reported that this simplification plays an important role in meeting the life-quality demands made by farmers and their families. These simplifications trigger changes in work patterns by cutting the number of on-farm work tasks and the daily number of hours at work (Ferris et al., 2006).

Technical solutions designed to simplify the herd management have different impacts on the farm systems. They can readjust an element of the production system without damaging the way it is running or else trigger more wide-reaching change. In fact, once farmers more deeply integrate the labour issue into their project, more changes in the technical and/or economic performances of the farm system and in trade-off between both will happen (Cournut \& Dedieu, 2005; Hostiou \& Dedieu, 2012).

Solutions involving technical managing aggregate popularity including those that challenge current models of technical productivity like milking once a day, seasonally throughout the year (Pomiès et al, 2008).

The improvement of DPS equipments allows for the enhancement of work productivity (Sidot, 2006; Hostiou et al., 2010; Winsten et al., 2010), contributing to the increase of the room for manoeuvre in time from the farmers. For example, in the transport of forages, on the one hand, farmers use animal cart which has the ability to transport $500 \mathrm{~kg}$ of forages per day and; on the other hand, farmers that use tractor cart have the ability to transport $2000 \mathrm{~kg}$ per day, considering the same total quantity to be carried. The difference in working time spent during the transport of forage between the two conditions is expressive. However, the improvement of the DPS equipments may also induce new demands expressed by the farmers for their work (Nicourt \& Souron, 1989), e.g., to receive information enabling the use new equipments.

The composition of the workforce (number and type of workers) also contributes to explain the room for manoeuvre in time. The largest DPS, used workforce from employees (workers outside the basic group) like other countries where the livestock farms are progressively becoming more industrialized (Yeamkong et al., 2010). But small farmers are also able to substitute familiar work with permanent employees, to delegate routine work in order to have time for an off-farm activity or to avoid arduous tasks (Nicholson et al., 2004), as it occurs in one of the sampled DPS. Despite not being a goal of this study, we might say that the expectations of the farmer for their work are not the same when they perform it by themselves or with other persons (Cournut et al., 2008; Rault, 2006).

\section{Conclusions}

The simplification of the herd management, the greater dimension of equipments and workforce composition allowed decreasing working time in the production systems. More complex conditions exist in the production systems with one worker only in the basic group who performs many routine works. A more comfortable condition exists in the production systems where the worker from the basic group delegates most part of the work, where the herd management is simplified and more equipped.

\section{Acknowledgements}

The authors would like to thank Institut National de La Recherche Agronomique (INRA), Universidade Estadual de Maringá (UEM) and the EMATER Institute, which supported this study; and CAPES, for providing the Sandwich Fellowship. Thanks also to the EMATER extension worker who helped during the sampling and interviews; and to Jean-Yves Pailleux, Cesar Poli, Silvia Cristina Aguiar, Jael Maria Braga Carneiro and especially the farmers who also collaborated with this study.

\section{References}

BERTIN, J. Le graphique et le traitement graphique de l'information. Paris: Flammarion, 1977. 273p.

CHAUVAT, S.; SEEGERS, J.; N'GUYEN THE, B. et al. Le travai d'astreinte en élevage bovin laitier: Synthèse nationale d'enquêtes bilan-travail. Analyse des aspirations et des solutions envisagées par les éleveurs du dispositif Réseaux d'élevage. Paris: Institut de 1'Elevage, 2003. 51p. Available at: $<$ http://78.155.145.72/html/html1/IMG/pdf/855-Resume_Synt_ Nat_Travail_BL.pdf> Accessed on: Nov. 3, 2011. 
COURNUT, S.; DEDIEU, B. Simplification des conduites d'élevage en bovins laitiers. Cahiers Agricultures, v.14, n.6, p.541-547, 2005.

COURNUT, S.; CHAVAUT, S. Work organization in livestock farms and farm liveability: Research findings from France. In: DARNHOFER, I.; GRÖTZER, M. (Eds). Proceedings of $9^{\text {th }}$ European IFSA Symposium, Building sustainable rural future: The added value of systems approaches and Applied Life Sciences. Vienne, Austria, 2010. p.1148-1157.

COURNUT, S.; HOSTIOU, N.; PAILLEUX, J.Y. Adaptation of work arrangements on dairy farms in France. In: DEDIEU, B.; ZASSERBEDOYA, S. (Eds.) Proceedings of the 8th European IFSA Symposium: Empowerment of the rural actors: a renewal of farming systems perspectives. Clermont-Ferrand, França, 2008. p.393-402.

COURNUT, S.; JOURDAN, A. Analyse de groupe des Bilans Travail - Guide méthodologique. Paris: Institut de l'Élevage, 2008. 63p.

COURNUT, S.; HOSTIOU, N. Adaptations des systèmes bovins laitiers pour réduire la contrainte travail. Une étude en Ségala. Cahiers Agricultures, v.19, p.348-353, 2010.

DEDIEU, B.; COULOMB, S.; SERVIÈRE, G. et al. Bilan Travail pour l'étude du fonctionnement des exploitations d'élevage. Edition 1993 modifiée. Collection Lignes. Paris: Institut de l'élevage; Inra éditions, 2000. 27p.

DEDIEU, B.; SERVIÈRE, G. Organisation du travail et fonctionnement des systèmes d'élevage. Rencontres Recherches Ruminants, Paris, 2001. p.245-250.

DEDIEU, B.; SERVIÈRE, G. Les modèles du travail en élevage : points de vue de zootechniciens des systèmes d'élevage. In: BÉGUIN, P.; DEDIEU, B.; SABOURIN, E. (Eds.). Le travail en agriculture dans les sciences pour l'action. Paris: L'Harrmattan, 2011. p.144-170

DEDIEU, B.; INGRAND, S. Incertitude et adaptation: cadres théoriques et application à l'analyse de la dynamique des systèmes d'élevage. INRA Productions Animales, v.23, p.81-90, 2010.

DEDIEU, B.; SERVIÈRE, G. ; MADELRIEUX, S. et al. Comment appréhender conjointement les changements techniques et les changements du travail en élevage? Cahiers Agricultures, v.15, p.506-513, 2006.

ERRINGTON, A.; GASSON, R. The increasing flexibility of the farm and horticultural workforce in England and Wales. Journal of Rural Studies, v.12, n.2, p.127-141, 1996.

FAGON, J; SABATTE, N. Référentiel travail en élevages bovins lait. Synthèse de 190 Bilans Traval. Institute de l'Élevage, 2011. 34p. Available at: <www.inst-elevage.asso.fr/IMG/pdf_3_ Referentiel_BT_bovin_lait_22 juillet_2011_WEB.pdf $>$. Accessed on: Sep. 10, 2012.

FERRIS, C.P.; FROST, J.; BINNIE, R.C. et al. Dairy cows performance and labour inputs associated with two silage feeding systems, Grass Forage Science, v.61, n.3, p.304-314, 2006.

FIORELLI, C.; DEDIEU, B.; PAILLEUX, J-Y. Explaining diversity of livestock-farming management strategies of multiple-job holders: importance of level of production objectives and role of farming in the household. Animal, v.1, n.8, p.1209-1218, 2007.

GIRARD, N.; BELLON, S.; HUBERT, B. et al. Categorizing combinations of farmers' land use practices: an approach based on examples of sheep farms in the south of France. Agronomie, v.21, p.435-459, 2001 .

GUILLAUMIN, A.; KLING-EVEILLARD, F.; MARTY, M. Attentes des éleveurs laitiers d'Aquitaine en matière de qualité de vie et de conditions de travail. Rencontres Recherches Ruminants, v.1, p.208, 2004.

HOSTIOU, N.; DEDIEU, B. Diversity of forage system work and adoption of intensive techniques in dairy cattle farms of Amazonia. Agronomy for Sustainable Development, v.29, p.535-544, 2009.
HOSTIOU, N.; DEDIEU, B. Le rôle de la conduite technique dans la cohérence d'une organisation du travail : une étude en élevage laitier (Ségala, France). In: BÉGUIN, P.; DEDIEU, B. (Eds.). Le travail en agriculture: son organisation et ses valeurs face à l'innovation. Paris, L'Harmattan, 2010. p.171-188.

HOSTIOU, N.; DEDIEU, B. A method for assessing work productivity and flexibility in livestock farms. Animal, v.6, p.852-862, 2012.

HOSTIOU, N.; DEDIEU, B.; MADELRIEUX, S. et al. Relations entre organisation du travail et taille des exploitations laitières : une étude à Moc Chau (Vietnam). Cahiers Agriculture, v. 19, n.5, p.323-330, 2010.

HOSTIOU, N.; TOURRAND, J.F.; VEIGA, J.B. Organisation du travail dans des élevages familiaux lait-viande sur un front pionnier amazonien au Brésil. Etude à partir de sept enquêtes "bilan travail". Revue Elevage et Médicine Vétérinaire des Pays Tropicaux, v.58, p.167-173, 2005.

INSTITUTO BRASILEIRO DE GEOGRAFIA E ESTATÍSTICA IBGE. Ministério do Planejamento, Orçamento e Gestão. Censo Agropecuário 2006. Rio de Janeiro: IBGE, 2009. 777p.

LANDAIS, E. Recherche sur les systèmes d'élevage. Questions et perspectives. Document de travail de l'INRA. Paris, 1987. 68p.

LANDAIS, E. Principes de modélisation des systèmes d'élevage - Approches graphiques. Les Cahiers de la Recherche Développement, v.32, p.82-95, 1992.

LANDAIS, E.; BONNEMAIRE, J. La zootechnie, art ou science? Entre nature et société, l'histoire exemplaire d'une discipline finalisée. Courrier de l'Environnement de l'INRA, n.27, p.23-44, 1996.

MADELRIEUX, S.; DEDIEU, B. Qualification and assessment of work organization in livestock farms. Animal, v.2, p.435-446, 2008.

MASEDA, F.; DIAZ, F.; ALAVREZ, C. Family dairy farms in Galicia (NW Spain): classification by some family and farm factors relevant to quality of life. Biosystems Engeering, v.87, p.509-521, 2004.

MILLEVILLE, P. Recherches sur les pratiques des agriculteurs. Les Cahiers de la Recherche Développement, v.16, p.3-7, 1987.

NICHOLSON, C.F.; THORNTON, P.K.; MUINGA, R.W. Householdlevel Impacts of Dairy Cow Ownership in Coastal Kenya. Journal of Agricultural Economics, v.55, p.175-195, 2004.

NICOURT, C.; SOURON, O. Incidences de quelques innovations sur les conditions de travail des agriculteurs. Économie rurale, v.192-193, p.110-114, 1989.

NOZIĖRES, M.O.; MOULIN, C.H.; DEDIEU, B. The herd, a source of flexibility for livestock farming systems faced with uncertainties? Animal, v.5, p.1442-1457, 2011.

POMIÈS, D.; MARNET, P.G.; COURNUT, S. et al. Les conduites de traite simplifiées en élevage laitier : vers la levée de l'astreinte biquotidienne. Inra Productions Animales, v.21, p.59-70, 2008.

RAULT, G. Approche sociologique en élevage et questions sur le conseil agricole. Fourrages, v.185, p.29-35, 2006.

SIDOT, G. L'efficacité du travail et la qualité de vie dans les élevages laitiers en France et en Europe. Fourrages, v.185, p.17-24, 2006.

TESSIER, J.H. Relations entre techniques et pratiques. Bulletin de I'INRAP, n.38, 1979. 18p

ULBRICHT, L. Relatório parcial do projeto diagnóstico e recomendações em ergonomia: Aplicação no estudo dos distúrbios osteomusculares relacionados ao trabalho dos ordenhadores do Estado do Paraná. Curitiba: UFPR, 2007. 218p.

WINSTEN, J.R.; KERCHNER, C.D.; RICHARDSON, A. et al.. Trends in the Northeast dairy industry: Large-scale modern confinement feeding and management-intensive grazing. Journal of Dairy Science, v.93, p.1759-1769, 2009.

YEAMKONG, S.; KOONAWOOTRITTIRON, S.; ELZO, M.A. et al. Effect of experience, education, record keeping, labor and decision Making on monthly milk yield and revenue of dairy farms supported by a Private Organization in Central Thailand, Asian Australasian Journal of Animal Sciences, v.23, p.814-824, 2010. 